\title{
Optimization of germination and initial quality of seedlings of Prunus persica tree rootstocks ${ }^{1}$
}

\author{
Aline das Graças Souza ${ }^{2 *}$, Victor Mouzinho Spinelli², Rauny Oliveira de Souza², \\ Oscar José Smiderle ${ }^{3}$, Valmor João Bianchi ${ }^{2}$
}

\begin{abstract}
The present study evaluated the germination potential of seeds from eight peach tree rootstocks under different stratification methods, aiming at the production of high quality seedlings. In the first experiment, seeds with endocarp from eight genotypes ('Aldrighi', 'Capdeboscq', 'Flordaguard', 'Okinawa', 'Okinawa roxo', 'Tsukuba 1', 'Tsukuba 2', 'Tsukuba 3') were stratified on sand and moist vermiculite, at $7{ }^{\circ} \mathrm{C}$ for 60 days. In the second experiment, endocarpless seeds of the same genotypes were stratified on Petri dishes at $7{ }^{\circ} \mathrm{C}$. In the third experiment, the time at which at least $75 \%$ of the seedlings reached transplanting height ( $15 \mathrm{~cm}$ high) was verified. The endocarp was a limiting factor for seed germination of the eight rootstocks, since the highest germination percentages were $21 \%$ and $48.3 \%$ for 'Aldrighi' and 'Capdeboscq', respectively. Germination of 'Okinawa' was only $19.2 \%$ and $4.2 \%$, in sand and vermiculite, respectively. Seeds stratified without the endocarp, showed $100 \%$ germination, except for 'Flordaguard' and 'Tsukuba 2' and 3', with 93\% germination. Seed mass presented a positive correlation with the germination speed index and the initial growth of the seedlings. 'Aldrighi' and 'Capdeboscq' presented more vigorous seedlings with greater growth in height, stem diameter, and Dickson quality index.
\end{abstract}

Index terms: peach, physiological and physical dormancy, seed mass, vigor, Dickson quality index.

\section{Otimização da germinação e qualidade inicial dos seedlings de porta-enxertos de Prunus persica}

\begin{abstract}
RESUMO - Objetivou-se avaliar o potencial germinativo de sementes de oito porta-enxertos de pessegueiro, sob diferentes métodos de estratificação, visando à produção de seedlings com alta qualidade. No primeiro experimento, sementes com endocarpo de oito genótipos de pessegueiros ('Aldrighi', 'Capdeboscq', 'Flordaguard', 'Okinawa', 'Okinawa roxo', 'Tsukuba 1', 'Tsukuba 2', 'Tsukuba 3') foram estratificadas em areia e vermiculita úmida, à $7^{\circ} \mathrm{C}$ por 60 dias. No segundo experimento, sementes sem endocarpo foram estratificadas em placas de Petri, à $7{ }^{\circ} \mathrm{C}$. No terceiro experimento avaliou-se o tempo em que pelo menos $75 \%$ dos seedlings atingissem o ponto de transplantio (15 cm de altura). O endocarpo revelou ser uma barreira limitante na germinação das sementes dos oito porta-enxertos, pois as maiores porcentagens de germinação foram $21 \%$ e $48,3 \%$, para 'Aldrighi' e 'Capdeboscq', respectivamente. A germinação de 'Okinawa' foi de apenas 19,2\% e 4,2\%, em areia e vermiculita, respectivamente. Sementes estratificadas sem o endocarpo, apresentaram $100 \%$ de germinação, exceto para 'Flordaguard', 'Tsukuba 2' e 3', com 93\% de germinação. Verificou-se correlação positiva da massa de sementes com o índice de velocidade de germinação e o crescimento inicial dos seedlings. 'Aldrighi' e 'Capdeboscq' apresentam seedlings mais vigorosos, com maior crescimento em altura, diâmetro do caule e índice de qualidade Dickson.
\end{abstract}

Termos para indexação: pessegueiro, dormência física e fisiológica, massa de sementes, vigor, índice de qualidade de Dickson.

\section{Introduction}

In Brazil, peach culture has relevant social and economic importance, mainly in the Southern and Southeastern regions.

${ }^{1}$ Submitted on 11/08/2016. Accepted for publication on $02 / 14 / 2017$.

${ }^{2}$ Departamento de Botânica, Universidade Federal de Pelotas, 96010-900 Pelotas, RS, Brasil.
Rio Grande do Sul (RS) stands out in terms of crop area and peach production, however, its average productivity is lower when compared with other states (Fachinello et al., 2011). This low productivity is attributed, in part, to the quality of
${ }^{3}$ Empresa Brasileira de Pesquisa Agropecuária, Centro de Pesquisa Agroflorestal de Roraima, Caixa Postal 133, 69301-970 - Boa Vista, RR, Brasil.

*Corresponding author < alineufla@hotmail.com> 
the material utilized in seedling production, especially with regard to the types of rootstock used and the way they are obtained (Timm et al., 2015).

Peach trees are mainly produced through grafting of the scion cultivar into a rootstock. In turn, rootstock multiplication can be performed by sexual (seeds) and asexual (cuttings or in vitro) methods, but in Brazil the sexual method is still the most widely utilized (Fischer et al., 2013; Iliev et al., 2012). In the Southern region of RS, the main production center of stone fruits and Prunus plants (peaches, nectarines, and Japanese plum), the rootstocks to graft the scion cultivars are produced from seeds derived from endocarps (pits) obtained in the canned peach industries (Fachinello et al., 2011). After stratification, they are sown in the field for germination, seedling growth and subsequent grafting of the scion cultivars.

This type of plant material is not adequate for use in the production of rootstocks due to the varietal mixture and the high genetic variability of seeds of the scion cultivars. This results in seedling rootstocks with marked differences in terms of adaptation to the edaphoclimatic conditions, tolerance and/or resistance to both biotic and abiotic stresses, high desuniformity in germination and plant growth, resulting into poor stand of plants in the nursery and in the orchards (Paula et al., 2011; Messchmidt et al., 2015).

In addition, seeds of different peach cultivars can differ greatly in degree of dormancy, which is determined by physiologic factors and by the physical resistance promoted by the endocarp. In this case, exposure to cold is required to break dormancy and activate peach seed germination (Wagner Júnior et al., 2013). Seeds not exposed to the adequate conditions for overcoming dormancy may not germinate or may produce abnormal seedlings, with physiological symptoms of dwarfism. Such anomalies of physiological nature are associated with delay of seedling growth, reducing the plant stand in the nursery (Martins et al., 2014).

In order to improve nursery productivity and seedling quality, it is fundamental to use rootstocks selected for such a goal and seeds in good sanitary conditions, besides providing adequate stratification time. These factors allow high production rates and homogeneity in germination. Enhancement of the germination process can reduce the time to obtain rootstocks fit for grafting and, consequently, decrease production costs for the nursery.

Among the different genotypes selected for use as rootstocks, 'Okinawa' is currently utilized widely in the Southeastern region, due to its high vigor that it transmits to the scion cultivar and for its resistance to root-knot nematodes (Meloidogyne spp). In Rio Grande do Sul, in addition to the stones obtained in industries, seeds of the cv. 'Capdeboscq' have been utilized in the production of rootstocks for a variety of peach tree and plum tree scions since they have a late cycle, which enables adequate development of the embryo (Fachinello et al., 2005). Other recent alternatives of rootstocks (Picolotto et al., 2012) include 'Tsukuba 1' and 'Flordaguard', due mainly to the resistance to Meloidogyne spp. and their good adaptation to the less rigorous winter of the Southern region. Others peach rootstoks have been introduced in Brazil such as 'Tsukuba 2', 'Tsukuba 3', and 'Okinawa roxo', but little is known about the propagation potential and the characteristics they induce in the scion cultivars.

Understanding how stratification conditions for seeds of different Prunus cultivars affect germination rate, germination speed and emergence index, as well as seedling stand, is fundamental to identify rootstocks with the greatest potential to optimize plant production. In that sense, this study evaluated the germination potential of seeds of eight peach tree rootstocks under different stratification methods, aiming at the production of high quality seedlings for use as rootstocks.

\section{Material and Methods}

\section{Description of the study area and general plant material preparation}

The experiment was carried out in the Plant Molecular Physiology Laboratory and the greenhouse of the Botany Department-IB-UFPel. The propagation material consisted of endocarps (pits) from mother plants of eight cultivars of the germoplasm collection of Prunus rootstocks, maintained in the Universidade Federal de Pelotas - Brasil.

When ripe, the fruits were harvested, the fruit pulp was removed and the endocarps were washed in running tap water, followed by soaking the endocarps in fungicide solution (Orthocid ${ }^{\circledR} 500-12 \mathrm{mg} \mathrm{L}^{-1}$ ) for 12 hours, and then shade-drying. After that step, the asepsis of all the material utilized in the experiment was performed according to the methodology proposed by Picolotto et al. (2007). To reach the objectives of the study, three independent experiments were conducted, as follow.

Experiment 1: Prunus persica seed stratification with endocarps

Seeds with endocarps intact were placed in plastic nets, that were accommodated in plastic boxes $(40 \times 27 \times 10 \mathrm{~cm})$ and completely wrapped by a $3 \mathrm{~cm}$ layer of medium sand (substrate 1) or vermiculite (substrate 2). Afterwards, they were put into BOD for 60 days, at $7 \pm 0.5^{\circ} \mathrm{C}$. The substrates were moistened, to maintain humidity between $85-90 \%$. The experimental design was completely randomized in factorial 
scheme $2 \times 8$, with four replications. Each replication consisted of 50 endocarps, amounting to 200 endocarps per treatment. The factors evaluated were: eight peach rootstocks ('Aldrighi', 'Capdeboscq', 'Flordaguard', 'Okinawa', 'Okinawa roxo', 'Tsukuba 1', 'Tsukuba 2', 'Tsukuba 3') and two substrates for stratification (washed medium sand and fine vermiculite).

Experiment 2: Prunus persica seed stratification without endocarp

In the same period as Experiment 1, seeds from the same peach rootstocks (described in Experiment 1), but without endocarp, were submitted to germination. The endocarps were broken, with further weighing of the individual fresh mass of the seeds on a precision balance $(0.001 \mathrm{~g})$. Then the seeds were disinfected with $2 \%$ sodium hypochlorite solution for 5 minutes, and washed three times in distilled water. Later, 25 seeds were placed onto each Petri dish, containing filter paper which was moistened with $4 \mathrm{~mL}$ of fungicide solution $\left(\right.$ Orthocid $^{\circledR} 500-12 \mathrm{mg} \mathrm{L}^{-1}$ ). The Petri dishes were closed, sealed with parafilm and taken to the BOD at $7 \pm 0.5^{\circ} \mathrm{C}$ in the absence of light, where they remained for 25 days, a period that allowed germination of more than $90 \%$ of all the seeds.

During stratification, every two days the seeds were observed with the purpose of verifying the start of radicle emission in order to calculate the germination speed index. The experimental design was a completely randomized scheme with four replications of 50 seeds, amounting to 200 seeds per treatment.

\section{Variables assessed in experiments 1 and 2}

The variables were percent of germination ( $\%$ G), germination speed index (GSI), mass of the endocarp plus seed, and mass of the seeds. The GSI was estimated by the formula proposed by Maguire (1962), expressing the ratio between the number of germinated seeds and the evaluation day.

\section{Experiment 3: Growth analysis of eight Prunus persica rootstocks}

After 25 days of stratification (in Petri dish, at $7 \pm 0.5^{\circ} \mathrm{C}$ ), the germinated endocarpless seeds were sown on polystyrene trays $\left(114 \mathrm{~cm}^{3}\right.$ per cell), containing as a substrate: $25 \%$ soil of the orchard $+25 \%$ vermiculite $+25 \%$ medium sand $+25 \%$ commercial substrate. Nutrient solution was added according to Souza et al. (2011a) with three weekly waterings.

The experiment was performed in a completely randomized design with eight treatments (eight cultivars), four replications of 20 seedlings per lot. Seedling height was recorded from sowing at two-day intervals until 22 days after sowing (DAS), when at least $75 \%$ of the seedlings reached transplanting height (15 cm high), as recommended by (Souza et al., 2011a).

At 22 DAS, the following variables were recorded: stem diameter (SD), at 2-cm from the soil level (in $\mathrm{mm}$ ); the SPAD index (chlorophyll meter model SPAD-502, Minolta, Osaka, Japan), the chlorophyll index (CHLI), and the nitrogen balance index (NBI), accessed by a Chlorophyll meter Dualex. The last three variables were registered between 9 and 11 hours a.m., using two fully expanded leaves located on the apical third of the seedling of 10 plants of each lot; two leaves per plant.

To obtain fresh and dry mass at 22 DAS, each seedling was divided into root and shoot. The roots were washed in running tap water, weighed and placed in paper bags, remaining under air forced circulation in a drying oven for 72 hours at $70{ }^{\circ} \mathrm{C}$. Then, they were again weighed on a precision balance $(0.01 \mathrm{~g})$ to determine shoot dry mass (SDM), root system mass (RSM), and from the sum of these, the total mass of the plant was calculated (TMS). In order to estimate the quality of the plants and their further survival in the field, the Dickson quality index (DQI) was calculated as proposed by (Dickson et al., 1960).

\section{Statistical analysis}

The means of the variables were submitted to the statistical analysis utilizing the software Sisvar (Ferreira, 2011), with variance analysis and regression for the factor time (days) and the Tukey test $(p \leq 0.05 \%)$ for the comparisons between the means of the other variables. The values of seed mass, GSI of the second experiment and plant height were submitted to the Pearson correlation analysis utilizing the software $\mathrm{R}$ Development (2008). The homogeneity and normality of the sampling distribution were surveyed by the Bartlett and Shapiro-Wilks tests.

\section{Results and Discussion}

\section{Germination potential of seeds with endocarps}

In the first experiment, no interaction among the factors occurred. Out of the eight cultivars evaluated, 'Aldrighi' and 'Capdeboscq' presented seeds with similar endocarp mass, varying from 3.91 to 4.22 grams per unit, which was greater than that of the other cultivars evaluated (Table 1).

The mean germination percentages of the seeds with endocarp ranged from 10.0 to $12.3 \%$, when stratified in the substrate vermiculite and sand, respectively (Table 1). Nevertheless, when stratified in vermiculite, the germination percentage of the seeds of 'Capdeboscq' was $56.52 \%$ as great as 'Aldrighi'. The other cultivars presented germination 
percentages smaller than $4.2 \%$.

When stratified in sand, 'Aldrighi' and 'Capdeboscq' presented no differences in germination, which ranged from 35.5 to $40.0 \%$ and was higher than that of the other cultivars (Table 1). Because of the small difference in the germination percentages recorded among treatments, the substrate sand can be utilized as an alternative in the process of stratification of stones of Prunus spp. rootstocks (Table 1). Sand is a much cheaper substrate and just as easy to obtain as vermiculite, allowing cost reduction in the production of peach tree seedlings.

In general, it was found that the effect of the physical barrier imposed by the endocarp led to a small percentage of germination not only in the cvs. Capdeboscq, Aldrighi and Okinawa, but also almost null germination percents of the seeds of 'Tsukuba 1', 2', 3' and 'Okinawa roxo' and 'Flordaguard', stratified both in sand and in vermiculite, for 60 days.

Seeds of 'Okinawa' presented a germination percentage of $19.2 \%$ and $4.2 \%$ when stratified in sand and vermiculite, respectively (Table 1), but that is larger than that described by Fischer at al. (2013) who found close to $0 \%$ germination for 'Okinawa' rootstock.

Following the same standard results obtained for the percentage of germination, 'Capdeboscq' and 'Aldrighi' cultivars showed higher GSI values, not differing from each other when stratified in vermiculite, but in sand 'Capdeboscq' presented GSI 60\% higher in relation to 'Aldrighi' (Table 1).

Based on the results of the present study, for these cultivars, seed germination is significantly restricted when the physical barrier (endocarp) is not eliminated, especially the cultivars selected for use as rootstocks. In plants of temperate climate, the physiological dormancy of seeds is always present and needs to be overcome for germination to occur. In several stone fruits, in addition to physiological dormancy, the endocarp protects the seeds from biotic and abiotic stressors, in field conditions or during fruit/endocarp processing and storage. According to Poletto et al. (2016), the endocarp can limit or even prevent germination, bringing about lack of uniformity in the seedling stand, which was also confirmed by Fischer et al. (2013) and corroborates our results.

\section{Germination potential of seeds without endocarps}

The individual fresh weight of 'Capdeboscq' seeds was higher compared to other cultivars, with $0.35 \mathrm{~g}$ per seed, followed by 'Aldrighi' and 'Okinawa roxo' which did not differ from each other. The lowest fresh weight values were for 'Flordaguard' and 'Okinawa' with $0.28 \mathrm{~g}$, representing an average mass of seed $20 \%$ lower than that recorded for 'Capdeboscq' seeds (Table 2).

In addition, in experiment 1 , the greatest mean mass
Table 1. Mean values for mass of seeds plus endocarp (g), germination percentage $(\%)$ and germination speed index (GSI) of eight peach tree rootstocks in two substrates at $7^{\circ} \mathrm{C}$ for 60 days.

\begin{tabular}{lccc}
\hline \multirow{1}{*}{ Cultivars } & \multicolumn{3}{c}{ Vermiculite } \\
\cline { 2 - 4 } & $\begin{array}{c}\text { Mass of seed } \\
(\text { g.seed })^{-1}\end{array}$ & $\begin{array}{c}\text { Germination } \\
\%\end{array}$ & GSI \\
\hline Aldrighi & $3.91 \mathrm{a}$ & $21.0 \mathrm{~b}$ & $1.34 \mathrm{a}$ \\
Capdeboscq & $4.18 \mathrm{a}$ & $48.3 \mathrm{a}$ & $1.52 \mathrm{a}$ \\
Flordaguard & $3.23 \mathrm{~b}$ & $2.5 \mathrm{c}$ & $0.08 \mathrm{c}$ \\
Okinawa & $2.62 \mathrm{c}$ & $4.2 \mathrm{c}$ & $0.34 \mathrm{~b}$ \\
Okinawa roxo & $2.93 \mathrm{bc}$ & $0.7 \mathrm{~d}$ & $0.00 \mathrm{c}$ \\
Tsukuba 1 & $3.22 \mathrm{~b}$ & $0.0 \mathrm{~d}$ & $0.00 \mathrm{c}$ \\
Tsukuba 2 & $2.97 \mathrm{bc}$ & $2.5 \mathrm{c}$ & $0.08 \mathrm{c}$ \\
Tsukuba 3 & $2.96 \mathrm{bc}$ & $0.7 \mathrm{~d}$ & $0.01 \mathrm{c}$ \\
\hline Mean & 3.25 & 10.0 & 0.42 \\
\hline & Sand & & \\
\hline Aldrighi & $4.01 \mathrm{a}$ & $35.5 \mathrm{a}$ & $0.71 \mathrm{~b}$ \\
Capdeboscq & $4.22 \mathrm{a}$ & $40.0 \mathrm{a}$ & $1.79 \mathrm{a}$ \\
Flordaguard & $3.12 \mathrm{~b}$ & $2.5 \mathrm{c}$ & $0.13 \mathrm{c}$ \\
Okinawa & $2.61 \mathrm{c}$ & $19.2 \mathrm{~b}$ & $0.79 \mathrm{~b}$ \\
Okinawa Roxo & $2.99 \mathrm{bc}$ & $0.0 \mathrm{c}$ & $0.00 \mathrm{c}$ \\
Tsukuba1 & $3.21 \mathrm{~b}$ & $0.0 \mathrm{c}$ & $0.00 \mathrm{c}$ \\
Tsukuba2 & $2.97 \mathrm{bc}$ & $0.0 \mathrm{c}$ & $0.00 \mathrm{c}$ \\
Tsukuba3 & $2.96 \mathrm{bc}$ & $0.0 \mathrm{c}$ & $0.00 \mathrm{c}$ \\
\hline Mean & 3.26 & 12.03 & 0.43 \\
\hline C.V.\% & 5.73 & 16.5 & 12.65 \\
\hline
\end{tabular}

Means followed by the same small letter do not differ from one another by the Tukey test $(\mathrm{p} \leq 5 \%)$.

Table 2. Mean values of fresh mass of the individual endocarpless seeds $(\mathrm{g})$, germination percentage (\%) and germination speed index (GSI) obtained from eight peach tree rootstocks stratified at $7{ }^{\circ} \mathrm{C}$ for 25 days.

\begin{tabular}{lccc}
\hline \multicolumn{1}{c}{ Cultivars } & Mass $(\mathrm{g})$ & Germination $\%$ & GSI \\
\hline Aldrighi & $0.32 \mathrm{~b}$ & $100 \mathrm{a}$ & $8.93 \mathrm{~b}$ \\
Capdeboscq & $0.35 \mathrm{a}$ & $100 \mathrm{a}$ & $11.58 \mathrm{a}$ \\
Flordaguard & $0.28 \mathrm{~d}$ & $93 \mathrm{a}$ & $5.43 \mathrm{c}$ \\
Okinawa & $0.28 \mathrm{~d}$ & $100 \mathrm{a}$ & $6.23 \mathrm{c}$ \\
Okinawa roxo & $0.32 \mathrm{~b}$ & $100 \mathrm{a}$ & $6.99 \mathrm{bc}$ \\
Tsukuba1 & $0.30 \mathrm{c}$ & $100 \mathrm{a}$ & $6.98 \mathrm{bc}$ \\
Tsukuba2 & $0.30 \mathrm{c}$ & $93 \mathrm{a}$ & $5.49 \mathrm{c}$ \\
Tsukuba3 & $0.30 \mathrm{c}$ & $93 \mathrm{a}$ & $5.46 \mathrm{c}$ \\
\hline Mean & 0.31 & 97.40 & 7.13 \\
\hline C.V.\% & 2.10 & 4.35 & 14.40 \\
\hline
\end{tabular}

Means followed by the same small letter do not differ from one another by the Tukey test $(\mathrm{p} \leq 5 \%)$. 
of endocarps was for Capdeboscq and Aldrighi cultivars, which is related to the later ripening of fruits in relation to the other cultivars evaluated. According to Fachinello et al. (2005), in cultivars of later ripening, in addition to increased endocarp mass, the seeds present larger fresh mass and consequently better developed embryos, directly influencing the germination percent and the GSI.

When seeds were stratified without the endocarp, most of the cultivars presented $100 \%$ germination, except the cultivars Flordaguard, Tsukuba 2 and 3, which presented 93\% germination (Table 2). Rodrigues et al. (2008) evaluating the germination of seeds of Prunus sellowii Koehne, emphasized that the germination tests should be carried out without the endocarp, aiming to eliminate the physical dormancy caused by the endocarp, which can significantly limit germination potential. In our study, this can be demonstrated by comparing the results of percentage germination and GSI in experiment 1 (Table 1) and experiment 2 (Table 2).

In addition to acting as a physical barrier in the germination process (Ghayyad et al., 2010), the endocarp in peach seeds can also act as a barrier for the transfer of the cold necessary for the overcoming physiological dormancy during the seed stratification process (Souza et al., 2016).

Also, limiting the accumulation of cold needed for the activation of the embryo metabolism, which becomes necessary for an adequate and satisfactory germination rate (Reis et al., 2010). In relation to GSI, 'Capdeboscq' presented the highest GSI value (11.58) compared to other rootstocks. This value was $24 \%$ higher than that of 'Aldrighi' (8.93), which in turn did not differ from 'Okinawa roxo' and 'Tsukuba 1' (Table 2).

In the stratification method without the endocarp, the mean GSI was six times as great as that found in the stratification method with the endocarp (Tables 1 and 2), demonstrating that the endocarp break allows the seeds of $P$. persica to express their maximum vigor much more quickly.

Person correlation coefficient between the mass of seeds with GSI and initial growth of seedlings.

The Pearson correlation $\left(r_{p}\right)$ was calculated for the three variables for the eight peach rootstocks. The germination speed index (GSI) is a vigor indicator of the seeds and of the germinating potential under adverse conditions (Matos et al., 2015). A positive and highly significant correlation between the seed mass and GSI $\left(r_{p}=0.93\right.$ and $\mathrm{p}$-value $=0.001$ ) was found in the eight peach rootstocks evaluated. Therefore, the seeds with a high amount of reserve (expressed by higher mass) develop and establish more vigorous seedlings (Smiderle et al., 2016; Chukwudi and Agbo, 2014).

Initial height of the seedlings was also directly associated with the GSI, showing a positive significant correlation $\left(r_{p}=0.96\right.$ and $p$-valor $\left.=0.001\right)$, where 'Capdeboscq' presented the greatest vigor of the seedlings fit for transplanting at 16 DAS under greenhouse conditions (Figure 1). Scheer et al. (2012), evaluating the growth of Prunus brasiliensis in substrates based on Pinus spp bark and vermiculite, obtained a mean height of $13.9 \mathrm{~cm}$ at seven months after sowing. However, under the greenhouse conditions in our study, the time to obtain transplanting height of the seedlings is approximately five months shorter, which can result in an early period for grafting.

The data obtained for the variable height in this study corroborate with those of Souza et al. (2011b), working with the rootstock 'Okinawa' in a greenhouse, who obtained a transplanting time of 22 days after sowing. In studies with fruit-bearing species, it was found that seedlings with greater height and greater stem diameter presented greater initial growth potential in the field (Freitas et al., 2013). In this study, the means of the stem diameter of the eight peach rootstocks ranged between 1.88 and $2.99 \mathrm{~mm}$, at 22 DAS (Table 3).

Under conditions similar to our study, Picolotto et al. (2007) obtained seedlings of the 'Aldrighi', 'Capdeboscq' and 'Okinawa' with a mean height of $15.0 \mathrm{~cm}$ and diameter of $1.90 \mathrm{~mm}, 35$ days after germination. However, Schmitz et al. (2014), studying rootstocks 'Okinawa' and 'Capdeboscq' obtained a mean height of 12.72 and $15.30 \mathrm{~cm}$, respectively at 58 DAS. In our study, the height of seedlings from 'Capdeboscq' was of $15.0 \mathrm{~cm}$ at 22 DAS (Figure 1), therefore, the method of seedling production utilized here was effective to promote fast growth in a period that was 36 day earlier and to allow high quality of the seedlings.

\section{Morphophysiological characteristics and seedling quality of Prunus persica}

The growth results for the 'Aldrighi' and 'Capdeboscq' at 22 DAS showed the relationship among the factors influencing growth of height and dry matter mass gain, demonstrating the positive correlation between seed quality and seedling height (Figure 1), yield of shoot dry mass (SDM), root dry mass (RDM) and total dry mass (TDM), when compared with the other peach tree cultivars (Table 3 ). These traits are important to reach the grafting time quickly. According to Smiderle and Souza (2016), the DQI is a good indicator of plant quality for considering in its calculation the ratio of plant height by the respective stem diameter and the balance of biomass distribution. In seedlings of Pyrus spp. grown in a greenhouse, the greater the value of total dry weight of seedlings, the better the quality of the seedlings, expressing the robustness of this index in relating the morphological traits (Souza et al., 2015). It can be inferred that the cultivars Aldrighi and Capdeboscq 
present better seedling quality for use as rootstock, because they present a higher DQI when compared with the other cultivars (Table 3 ).

The Dickson quality index-(DQI) has been an option for inferring about the quality standard of plant development (Dickson et al., 1960). Regarded as an efficient index and recommended by several authors, the DQI takes into consideration variables such as total dry mass of plants, ratio between shoot height and stem diameter and ratio between shoot dry mass and root dry mass (Duarte et al., 2015; Mews et al., 2015).

Other variables for estimating plant growth rate at different developmental stages, such as the SPAD index, chlorophyll index and nitrogen balance index, can also be taken into consideration in the evaluation of plant nutritional quality.
Important variations in the nitrogen balance index (NBI) were for seedlings of the eight peach rootstocks, with significant differences in the dynamics of $\mathrm{N}$ absorption. Nitrogen is one of the mineral elements most demanded by plants and a constituent of proteins, nucleic acids and many other plant constituents, including membranes and several hormones and its availability is essential to stimulate and sustain vegetative growth (Scheer et al., 2012).

The highest NBI values were found in seedlings of the cultivars Aldrighi and Capdeboscq (Table 4), which also presented the greatest SPAD and CHLI index. The direct relationship between these indices, in each rootstock cultivar, is attributed to the fact that 50 to $70 \%$ of the total $\mathrm{N}$ of leaves is a constituent of the enzymes and pigments that are associated with chloroplasts (Souza et al., 2015).

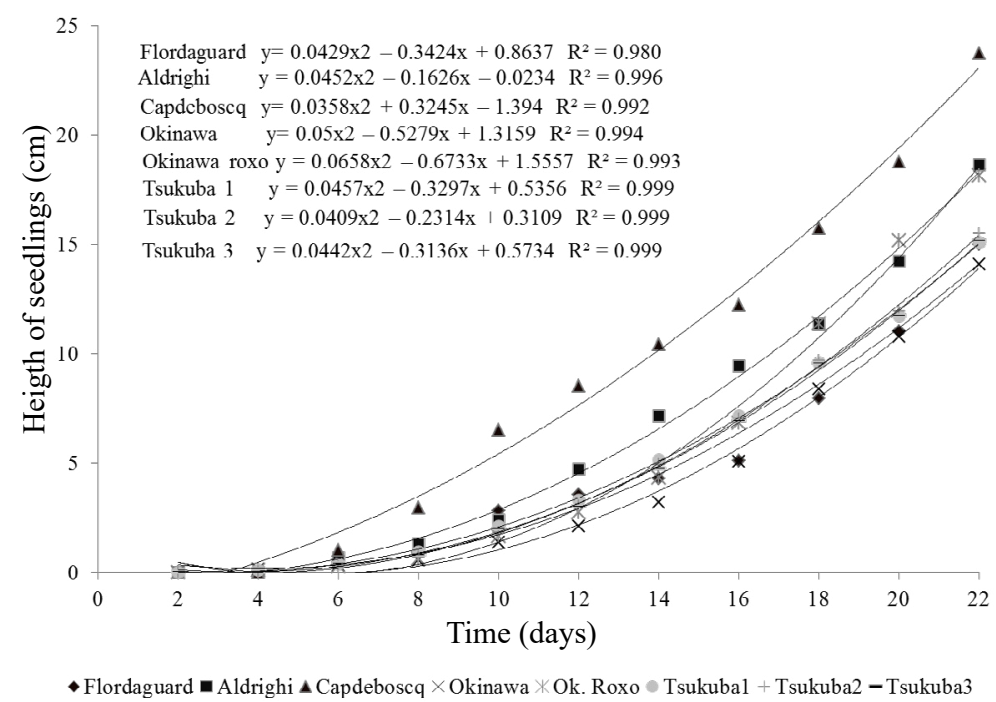

Figure 1. Growth in height of seedlings of eight peach tree rootstocks in greenhouse 22 days after sowing.

Table 3. Mean values for stem diameter (SD, mm), root fresh mass (RFM, g), shoot fresh mass (SFM, g), shoot dry mass (SDM, g), root dry mass (RDM, g), total dry mass (TDM, g) and Dickson quality index (DQI) of seedlings of eight peach rootstocks at $22 \mathrm{DAS}$, grown in greenhouse.

\begin{tabular}{lccccccl}
\hline \multicolumn{1}{c}{ Cultivars } & SD & RFM & SFM & SDM & RDM & TDM & DQI \\
\hline Aldrighi & $2.94 \mathrm{a}$ & $0.70 \mathrm{a}$ & $1.86 \mathrm{a}$ & $0.30 \mathrm{a}$ & $0.62 \mathrm{a}$ & $0.92 \mathrm{a}$ & $0.10 \mathrm{a}$ \\
Capdeboscq & $2.99 \mathrm{a}$ & $0.74 \mathrm{a}$ & $1.90 \mathrm{a}$ & $0.34 \mathrm{a}$ & $0.65 \mathrm{a}$ & $0.94 \mathrm{a}$ & $0.10 \mathrm{a}$ \\
Flordaguard & $2.43 \mathrm{~b}$ & $0.43 \mathrm{~d}$ & $1.04 \mathrm{f}$ & $0.15 \mathrm{~d}$ & $0.34 \mathrm{e}$ & $0.50 \mathrm{e}$ & $0.06 \mathrm{~cd}$ \\
Okinawa & $1.88 \mathrm{~d}$ & $0.50 \mathrm{c}$ & $1.05 \mathrm{f}$ & $0.12 \mathrm{e}$ & $0.32 \mathrm{e}$ & $0.45 \mathrm{f}$ & $0.05 \mathrm{~d}$ \\
Okinawa roxo & $2.20 \mathrm{c}$ & $0.63 \mathrm{~b}$ & $1.38 \mathrm{~d}$ & $0.18 \mathrm{c}$ & $0.47 \mathrm{c}$ & $0.65 \mathrm{c}$ & $0.06 \mathrm{~cd}$ \\
Tsukuba 1 & $2.24 \mathrm{c}$ & $0.61 \mathrm{~b}$ & $1.61 \mathrm{~b}$ & $0.21 \mathrm{~b}$ & $0.55 \mathrm{~b}$ & $0.75 \mathrm{~b}$ & $0.08 \mathrm{~b}$ \\
Tsukuba 2 & $2.20 \mathrm{c}$ & $0.52 \mathrm{c}$ & $1.53 \mathrm{c}$ & $0.18 \mathrm{c}$ & $0.52 \mathrm{~b}$ & $0.70 \mathrm{~b}$ & $0.07 \mathrm{~b}$ \\
Tsukuba 3 & $2.20 \mathrm{c}$ & $0.51 \mathrm{c}$ & $1.20 \mathrm{e}$ & $0.18 \mathrm{c}$ & $0.39 \mathrm{~d}$ & $0.58 \mathrm{~d}$ & $0.06 \mathrm{~cd}$ \\
\hline Mean & 2.38 & 0.58 & 1.44 & 0.27 & 0.48 & 0.68 & 0.07 \\
C.V.\% & 1.05 & 1.79 & 0.48 & 1.37 & 0.37 & 0.52 & 5.20 \\
\hline
\end{tabular}

Means followed by the same small letter do not differ from one another by the Tukey test $(\mathrm{p} \leq 5 \%)$. 
Table 4. Nitrogen balance index (NBI), chlorophyll index (CHLI), SPAD index in the production of seedlings of peach tree rootstocks in greenhouse at 22 DAS.

\begin{tabular}{lccc}
\hline \multicolumn{1}{c}{ Cultivars } & NBI & CHLI & SPAD \\
\hline Aldrighi & $20.62 \mathrm{a}$ & $22.95 \mathrm{a}$ & $38.36 \mathrm{a}$ \\
Capdeboscq & $20.50 \mathrm{a}$ & $23.14 \mathrm{a}$ & $38.81 \mathrm{a}$ \\
Flordaguard & $16.15 \mathrm{~b}$ & $20.95 \mathrm{~b}$ & $36.95 \mathrm{~b}$ \\
Okinawa & $14.69 \mathrm{c}$ & $18.94 \mathrm{c}$ & $34.92 \mathrm{c}$ \\
Okinawa roxo & $16.39 \mathrm{~b}$ & $20.17 \mathrm{~b}$ & $36.15 \mathrm{~b}$ \\
Tsukuba 1 & $16.77 \mathrm{~b}$ & $20.93 \mathrm{~b}$ & $36.27 \mathrm{~b}$ \\
Tsukuba 2 & $16.51 \mathrm{~b}$ & $20.24 \mathrm{~b}$ & $36.29 \mathrm{~b}$ \\
Tsukuba 3 & $16.32 \mathrm{~b}$ & $20.39 \mathrm{~b}$ & $36.19 \mathrm{~b}$ \\
\hline Mean & 17.25 & 20.96 & 36.74 \\
C.V.\% & 3.45 & 3.71 & 2.19 \\
\hline
\end{tabular}

Means followed by the same small letter do not differ from one another by the Tukey test $(\mathrm{p} \leq 5 \%)$.

Another factor that may explain the higher SPAD and CHLI in 'Capdeboscq' and 'Aldrighi' is the color of leaves. Therefore, more studies on seed germination and growth and initial development of the species of this genus can contribute to increased knowledge about production of peach rootstocks by seedlings, consequently to increased quality of plants produced, which will result in better fruit quality and yield in Prunus spp. orchards.

\section{Conclusions}

The stratification of seeds with endocarp in sand or vermiculite, for 60 days at $7{ }^{\circ} \mathrm{C}$, does not influence the percentage of seed germination of the eight peach rootstocks evaluated.

The peach endocarp is an important barrier that limits the percentage of seed germination.

The stratification of seeds without endocarp significantly increases the germination percentage, reduces the time for seedling transplanting and increases seedling standard of the eight peach rootstocks.

There is a positive correlation between peach seed mass and germination speed index and initial growth of seedlings, which is an important indicator of early plant production.

Seedlings of 'Aldrighi' and 'Capdeboscq' are the most vigorous among the eight peach rootstocks evaluated, expressed by the greater growth in height, stem diameter, and Dickson quality index.

\section{Acknowledgments}

The authors thank the Conselho Nacional de Desenvolvimento Científico e Tecnológico $(\mathrm{CNPq})$ for the financial support (Process number 482386/2010-0) and the Coordenação de Aperfeiçoamento de Pessoal de Nível Superior (CAPES) for the Postdoctoral scholarships (PNPD 03041/09-3).

\section{References}

CHUKWUDI, U.P.; AGBO, C.U. Influence of fruit characteristics on seeds and seedling emergence of fluted pumpkin (Telfairia occidentalis Hook F.). The Journal of Animal \& Plant Sciences, v.24, n.3, p.600-605, 2014. http://www.thejaps.org.pk/docs/v-24-2/35.pdf.

DICKSON, A.; LEAF, A.L.; HOSNER, J.F. Quality appraisal of white spruce and white pine seedling stock in nurseries. Forestry Chronicle, v.36, p.10-13, 1960. http://pubs.cif-ifc.org/doi/ abs/10.5558/tfc36010-1.

DUARTE, M.L.; PAIVA, H.N.; ALVES, M.O.; FREITAS, A.F.; MAIA, F.F.; GOULART, L.M.L. Growth and quality of seedlings of vinhático (Platymenia foliolosa Benth.) in response to the manuring with potassium and sulfur. Ciência Florestal, v.25, n.1, p.221-229, 2015. http://dx.doi.org/10.1590/1980-509820152505221.

FACHINELLO, J.C.; HOFFMANN, A.; NACHTIGALL, J.C. Propagation of fruit trees plants. Embrapa Information Technology, Brasília, p.221, 2005. http://dx.doi.org/10.1080/01140671.1995.9513912.

FACHINELLO, J.C.; PASA, M.S.; SCHMITZ, J.D.; BETEMPS, D. Situation and perspectives of temperate fruit crops in Brazil. Revista Brasileira de Fruticultura, v.33, (Special edition), p.109120, 2011. http://dx.doi.org/10.1590/S0100-29452011000500014

FERREIRA, D.F. Sisvar: A computer statistical analysis system. Ciência e Agrotecnologia, v.35, n.6, p.1039-1042, 2011. http:// dx.doi.org/10.1590/S1413-70542011000600001.

FISCHER, D.L.O.; ROSSAROLLA, M.D.; FISCHER, C.; OLIVEIRA, E.L.; GIACOBBO, C.L. Emergence of seedlings of rootstock of the peach when submitted to different periods of stratification. Revista Ciência Agronômica, v.44, n.1, p.199-204, 2013. http://dx.doi.org/10.1590/S1806-66902013000100025.

FREITAS, R.M.O.; NOGUEIRA, N.W.; PINTO, J.R.S.; TOSTA, M.S.; DOMBROSKI, J.L.D. Phosphate fertilizer in the initial development of sugar apple seedlings. Bioscience Journal, v.29, n.2, p.319-327, 2013. http://www.seer.ufu.br/index.php/ biosciencejournal/article/viewFile/13940/12269.

GHAYYAD, M.; KURBYSA, M.; NAPOLSY, G. Effect of endocarp removal, giberelline, stratification and sulfuric acid on germination of mahaleb (Prunus mahaleb L.) seeds. AmericanEurasian Journal of Agricultural \& Environmental Sciences, v.9, n.2, p.163-168, 2010. www.idosi.org/aejaes/jaes9(2)/10.pdf.

ILIEV, N.; PETRAKIEVA, A.; MILEV, M. Seed dormancy breaking of wild cherry (Prunus avium L.) seeds. Forestry Ideas, v.17, n.1, p.28-36, 2012. http://dx.doi.org/10.15177/seefor.14-12

MAGUIRE, J. D. Speed of germination-aid in selection and evaluation for seedling emergence and vigor. Crop Science, v.2, n.1, p.176-177, 1962. <http://www.scielo.br/scielo.php?script=sci nlinks\&ref $=000093$ \&pid $=$ S01013122201000030001500019\&lng=en $>$. 
MARTINS, A.S.; BIANCHI, V.J.; ZANANDREA, I.; SPINELLI, V.M.; FACHINELLO, J.C. Effects of seeds stratification on seedling emergence and initial development of peach rootstock. Cientifica, v.42, n.2, p.366-375, 2014. cientifica.org.br/index.php/cientifica/ article/download/538/357.

MATOS, A.C.B.; BORGES, E.E.L.; SILVA, L.J. Physiology of seed germination of Dalbergia nigra (Vell.) Allemão ex Benth. under different temperatures and exposure times. Revista Arvore, v.39, n.1, p.115-125, 2015. http://dx.doi.org/10.1590/010067622015000100011 .

MESSCHMIDT, A.A.; BIANCHI, V.J.; ZANANDREA, I.; MARTINAZZO, E.G.; RADMANN, E.B.; BACARIN, M.A. As exchange and antioxidant activity of Prunus spp. rootstocks submitted to drought and waterlogging. Revista de la Facultad de Agronomía, v.114, n.1, p.71-81, 2015. http://www.agro.unlp.edu.ar/ revista/index.php/revagro/ article/view/397/179

MEWS, C.L.; SOUSA, J.R.L.; AZEVEDO, G.T.O.S.; SOUZA, A.M. Effect of hydrogel and urea on the seedling production of Handroanthus ochraceus (Cham.) Mattos. Floresta e Ambiente, v.22, n.1, p.107-116, 2015. http://dx.doi.org/10.1590/2179-8087.080814.

PAULA, L.A..; BIANCHI, V.J.; GOMES, C.B.; FACHINELLO, J.C. Reaction of peach rootstocks to Meloidogyne incognita. Revista Brasileira de Fruticultura, v.33, n.2, p.680-684, 2011. http://dx.doi. org/10.1590/S0100-29452011000200043.

PICOLOTTO, L.; BIANCHI, V.J.; GAZOLLA NETO, A.; FACHINELLO, J.C. Different potting mix on formation of withinpackage seedlings of peach. Scientia Agraria, v.8, n.2, p.119-125, 2007. http://dx.doi.org/10.1590/S0103-84782012005000034.

PICOLOTTO, L.; SCHMITZ, J.D.; PASA, M.D.S.; BIANCHI, V.J.; FACHINELLO, J.C. Vegetative and productive growth of peach tree cv. 'Maciel' grafted in different rootstocks. Ciência Rural, v.42, n.1, p.964-974, 2012. doi: http://dx.doi.org/10.5380/ rsa.v8i2.8375.

POLETTO, T.; MUNIZ, M.F.B.; POLETTO, I.; STEFENON, V.M.; MACIEL, C.G.; RABUSQUEL, J.E. Dormancy overcome and seedling quality of pecan in nursery. Ciência Rural, v.46, n.11, p.19801985, 2016. http://dx.doi.org/10.1590/0103-8478cr20150835.

R. DEVELOPMENT CORE TEAM. R: A language and environment for statistical computing, reference index version 2.8.0. $R$ Foundation for Statistical Computing. Vienna, 2008. http://www. scielo.br/scielo.php?script $=$ sci_nlinks\&ref $=000108 \&$ pid $=$ S01002945201300020001700023\&lng=en.

RODRIGUES, E.R.; HIRANO, E.; NOGUEIRA, A.C. Germinação de sementes de pessegueiro-bravo sob diferentes condições de luz e substrato. Scientia Agraria, v.9, n.1, p.91-94, 2008. http://revistas. ufpr.br/agraria/article/view/10142/8181

SCHEER, M.B.; CARNEIRO, C.; SANTOS, K.G. Seedlings growth of Prunus brasiliensis (Cham. \& Schltdl.) D. Dietr. in sewage sludge based compost and mineral fertilizer. Ciência Florestal, v.22, n.5, p.739-747, 2012. http://www.scielo.br/pdf/cflo/v22n4/1980-5098cflo-22-04-00739.pdf
SCHMITZ, J.D.; PASA, M.S.; FISCHER, D.L.O.; FACHINELLO, J.C.; BIANCHI, V.J. Performance of peach rootstocks in different crop systems for the production of 'Chimarrita' seedlings. Revista Ceres, v.61, n.3, p.293-297, 2014. doi:http://dx.doi. org/10.14583/2318-7670.v02n04a08.

SMIDERLE, O.J.; SOUZA, A.G. Production and quality of Cinnamomum zeylanicum Blume seedlings cultivated in nutrient solution. Revista Brasileira de Ciências Agrárias, v.11, n.2, p.104110, 2016.10. http://www.redalyc.org/articulo.oa?id=119046408007

SMIDERLE, O.J.; SOUZA, A.G.; SOUZA, A.A. Morphological aspects of seeds, emergence and growth of seedlings of surinam cherry trees sown at different depths. Journal of Plant Sciences, v.59, n.1, p.47-53, 2016. http://www.sciencepublishinggroup.com/ journal/paperinfo? journalid=215\&doi=10.11648/j.jps.20160405.15.

SOUZA, A.G.; CHALFUN, N.N.J.; FAQUIN, V.; SOUZA, A.A. Production of peach grafts under hydroponic conditions. Ciência e Agrotecnologia, v.35, n.2, p.322326, 2011a. http://www.scielo.br/scielo.php?script=sci nlinks\&pid=S01002945201500010024000020\&lng=en

SOUZA, A.G.; CHALFUN, N.N.J.; FAQUIN, V.; SOUZA, A.A. Production of pear trees grafted under hydroponic conditions. Scientia Agraria, v.12, n.1, p.266-268, 2011b. http://dx.doi. org/10.5380/rsa.v12i1.33696.

SOUZA, A.G.; CHALFUN, N.N.J.; FAQUIN, V.; SOUZA, A.A.; NETO, A.L.S. Dry matter and nutrient accumulation in grafted pear seedlings in hydroponic system. Revista Brasileira de Fruticultura, v.37, n.1, p.240-246, 2015. http://dx.doi. org/10.1590/0100-2945-020/14.

SOUZA, A.G.; SMIDERLE, O.J.; SPINELLI, V.M.; SOUZA, R.O.; BIANCHI, V.B. Correlation of biometrical characteristics of fruit and seed with twinning and vigor of Prunus persica rootstocks. Journal of Seed Science, v.38, n.4, p.322-328, 2016. http://dx.doi. org/10.1590/2317-1545v38n4164650.

TIMM, C.R.F.; SCHUCH, M.W.; TOMAZ, Z.F.P.; MAYER, N.A. Rooting of herbaceous minicuttings of peach rootstock under effect of indolebutyric acid (IBA). Semina, v.36, n.2, p.135-140, 2015. http://dx.doi.org/10.5433/1679-0359.2015v36n1p135

WAGNER JÚNIOR, A.; BRUCKNER, C.H.; SILVA, J.O.C.; SANTOS, C.E.M.; PIMENTEL, L.D.; MAZARO, S.M. Chilling requirement for seed germination and phonological observations on peach cultivars. Revista Ceres, v.60, n.3, p.234-241, 2013. http:// dx.doi.org/10.1590/S0034-737X2013000200012 